\title{
Políticas públicas de ações afirmativas para a Educação Superior: o Conselho Universitário como arena de disputas
}

Neusa Chaves Batista ${ }^{a}$

\section{Resumo}

Este artigo discute a emergência de políticas compensatórias, cujo foco central tem sido reservar vagas na Educação Superior pública para estudantes que, por razões de sua origem étnica, racial e/ou socioeconômica, não tiveram/têm acesso a esse nível da educação. Aborda a relação entre Estado, justiça social e democracia, procurando dar base teórico-conceitual ao estudo das políticas de ações afirmativas para a Educação Superior no Brasil. Utilizando-se o recurso metodológico da análise argumentativa, examina os embates e disputas estabelecidos em sessão do Conselho Universitário da Universidade Federal do Rio Grande do Sul, no ano de 2012, período de avaliação do programa de Ações Afirmativas implantado nessa universidade, em 2008. Como conclusão mais geral, postula que os embates e disputas estabelecidos pelos segmentos do Conselho, em especial, dos docentes e dos discentes, expressam as disputas presentes na sociedade brasileira por um modelo de justiça social em face às políticas públicas de ações afirmativas para a Educação Superior.

Palavras-chave: Cotas para a Educação Superior. Conselho Universitário. Estado social. Justiça social e democracia. Universidade Federal do Rio Grande do Sul.

\section{Introdução}

Neste primeiro quartil do século XXI, a sociedade brasileira tem demonstrado maturidade ao abrir-se para discutir questões históricas relacionadas à desigualdade educacional no Brasil e seus efeitos sobre fenômenos sociais, como a pobreza e a miséria material de grande parte dos cidadãos brasileiros. O estopim dessa discussão se deu em função da emergência de políticas públicas de ações

\footnotetext{
a Universidade Federal do Rio Grande do Sul. Porto Alegre, Rio Grande do Sul, Brasil.
}

Recebido em: 13 Mar., 2014

Aceito em: 06 Ago., 2014 
afirmativas para a Educação Superior, com o objetivo de garantir que segmentos sociais historicamente excluídos desse nível da educação, a esse tivessem acesso. Trata-se de uma política pública de corte social, cuja oferta é focalizada para cidadãos que, por razões de sua origem étnica, racial e/ou socioeconômica, não tiveram/têm acesso à Educação Superior.

No âmbito acadêmico-científico, estudos (BARROZO, 2004; BARBOSA, 2009) têm demonstrado que a mobilidade intrafamiliar transgeracional ascendente de educação e renda no Brasil é minúscula frente às políticas públicas implementadas. O sistema educacional tem funcionado como um eficiente instrumento de reprodução das desigualdades sociais (ALMEIDA; NOGUEIRA, 2002), tal qual as que se reproduzem na sociedade capitalista brasileira. A inércia da parca educação e da pobreza entre gerações da mesma família marca o país com cicatriz brutal. A essa ferida, soma-se o caráter onipresente - profundo e velado, por resilientes cacoetes culturais e processos sociais - da desigualdade dos negros e indígenas (BARROZO, 2004).

As políticas públicas de ações afirmativas para a Educação Superior, enquanto fruto do citado contexto, oferecem momento privilegiado para flagrar os efeitos da inércia política e do preconceito da sociedade brasileira. Mas oferece, igualmente, uma oportunidade de escolha fundamental: ou reforça-se o ciclo do patrimonialismo político e do preconceito social que se arrastam desde o início de uma sociedade ainda sob o signo da escravidão ou procura-se rompêlo. Conforme Barrozo (2004, p. 133), "[...] como fragmento da experiência constitucional brasileira, o regime de distribuição de bens educacionais falha no teste da igualdade."

Assim, mesmo que, em 2012, das cerca de 50 milhões de matrículas da Educação Básica no Brasil, 83,5\% (aproximadamente 42 milhões) tenham sido realizadas na rede pública de ensino, esse percentual não se aproxima da realidade da Educação Superior pública. No que se refere à etapa do Ensino Médio, passagem obrigatória para o nível da Educação Superior, das cerca de 8 milhões de matrículas realizadas, 87,3\% (aproximadamente 7 milhões) foram efetivadas em instituições públicas (BRASIL, 2013a). Contudo, apesar de os dados revelarem que a Educação Básica no Brasil é, predominantemente, pública, essa lógica se inverte quando se trata da Educação Superior pública. No que diz respeito à oferta de vagas para a Educação Superior, considerando-se o seu percentual de estabelecimentos, das 2.365 Instituições de Ensino Superior (IES) que participaram do Censo da Educação Superior em 2011, apenas 284 (12\%) são públicas, restando 2.081 
(88\%) privadas. Assim, as IES públicas cobriram, em 2011, 26,3\% das matriculas para graduação, enquanto as IES privadas, 73,7\% (BRASIL, 2013b).

Diversas pesquisas têm revelado que a maior parte dos estudantes que frequentam a Educação Básica pública não tem acesso à Educação Superior pública, em especial nos cursos de maior status social, cujos candidatos, em grande parte, são oriundos de escolas privadas, que atendem apenas $16,5 \%$ das matrículas da Educação Básica ( $c f$. AKKARI, 2001; NEVES; RAIZER; FACHINETTO, 2007; SOUZA, 2009; MONSMA; SOUZA; SILVA, 2013).

Com base nos dados citados (BRASIL, 2013a, 2013b), pode-se dizer que a demanda por Educação Superior no Brasil é, prioritariamente, atendida por IES privadas; com efeito, o acesso às IES públicas comprova-se elitizado. Logo, a Educação Superior pública no Brasil é um bem coletivo escasso e, como tal, é objeto de disputa social, que necessita de um modelo de justiça social que a regule. Assim, a focalização de políticas públicas educacionais faz sentido em contextos de comprovada desigualdade educacional, mesmo que, para tal, haja uma diferenciação social, ou uma "discriminação positiva", na distribuição do recurso público.

Na esteira dessas discussões e ações para a redução da desigualdade educacional na Educação Superior, em 2007, após problematização com a comunidade universitária e local, o Conselho da Universidade Federal do Rio Grande do Sul (CONSUN/UFRGS) aprova a instituição do programa de ações afirmativas (cotas sociais) da Universidade, com vigência efetiva a partir de 2008. Em 2012, passados cinco anos da implantação do Programa, mais uma vez o Conselho se reúne para discutir e avaliar os impactos da reserva de vagas para o ingresso de estudantes de escolas públicas e de estudantes de escolas públicas autodeclarados negros sobre os indicadores educacionais da Universidade, com vistas a estabelecer se a política deveria sofrer mudanças no seu formato inicial ou, ainda, sobre a sua continuidade ou não.

No escopo deste artigo, pretende-se analisar a 1.151 a $^{a}$ sessão do CONSUN/ UFRGS, realizada em 20 de julho de 2012, cujo foco central do debate foi a avaliação dos primeiros cinco anos do programa de ações afirmativas da Universidade. O estudo deu centralidade, em termos de base empírica, a dois pedidos de parecer de vistas ao parecer da Comissão Especial encarregada de emitir decisão de avaliação. Toma-se a instância do Conselho como uma arena de embates e disputas por um modelo de justiça social às políticas públicas de 
ações afirmativas para a Educação Superior na UFRGS. Considera-se, para tal, que toda a política pública de ações afirmativas incorpora, na sua base éticopolítica, uma noção de justiça social.

$\mathrm{Na}$ análise, salienta-se a excelência dada à fala, que pode se expressar tanto na palavra dita nas discussões orais quanto na palavra escrita (atas, pareceres, pedidos de vistas, documentos produzidos pelo Conselho). Assim, entende-se que toda a fala se desenrola em torno de um bloco básico chamado "argumento", que busca obter legitimidade social a partir de uma ideia central ou no princípio sobre o qual a fala está baseada. O "[...] argumento é uma ferramenta de mudança social, na medida em que pretende persuadir uma audiência em foco."(LIAKOPOULOS, 2002, p. 218).

Contudo, o esforço metodológico de encontrar a lógica linguística das diferentes formas de argumentação, de retórica e de estilística, assim como o princípio de sua eficácia simbólica, está condenado ao fracasso, caso não logre estabelecer a relação entre as propriedades do discurso, daquele que o pronuncia e da instituição que o autoriza a pronunciá-lo. Isto é, não se pode separar o instrumento linguístico de suas condições de produção e utilização (BOURDIEU, 1996).

O trabalho está organizado em quatro seções: na primeira seção, apresenta-se a introdução, com uma breve contextualização do tema, a justificativa e o objetivo do artigo; na segunda seção, há o esforço no sentido de trazer uma discussão sobre Estado, justiça social e democracia, no intuito de estabelecer uma reflexão teórico-conceitual acerca das políticas públicas de ações afirmativas para a Educação Superior enquanto direito social. Com efeito, discute-se um modelo de justiça social que, como incumbência do Estado social, não pode restringir-se à redistribuição de recursos materiais com a finalidade de corrigir apenas desigualdades socioeconômicas (dimensão de classe); tal modelo inclui a responsabilidade de combater e corrigir discriminações étnicas, raciais, religiosas e de gênero (dimensão de status); na terceira seção, procede-se à análise da 1.151. ${ }^{\mathrm{a}}$ sessão do CONSUN/UFRGS, com o objetivo de analisar e interpretar os principais embates e disputas estabelecidos pelos seus atores, em especial o impasse que se estabelece entre os segmentos docente e discente, no que se refere ao parecer da Comissão Especial de avaliação das ações afirmativas nomeada pela reitoria para emitir decisão de avaliação; na quarta seção, à guisa das considerações finais, retomam-se os principais pontos do texto para uma reflexão articulada com as condições mais gerais das políticas públicas de ações afirmativas para a Educação Superior no Brasil. 


\section{Estado, justiça social e democracia: quem garante o bem-estar social?}

Gostaria de salientar, nestas considerações iniciais, sob o ponto de vista das discussões sobre políticas públicas sociais, dentre as quais se inserem as políticas de ações afirmativas para a Educação Superior, o argumento central deste artigo sobre o papel do Estado na produção de políticas de bem-estar social. Defende-se a perspectiva de que está na origem do contrato social da modernidade a sua função de gerir o bem-estar econômico e social. Todavia, à medida que a esfera pública é apropriada pela lógica do capital, essa função acaba por ser absorvida por outras funções mais afeitas à manutenção da economia capitalista. Com efeito, a implantação de políticas estatais de corte social passa a ser motivo de luta pela garantia de direitos sociais, tornando-se conquistas da cidadania nacional.

A perspectiva acima aludida se dá em função de estabelecer, já de início, posicionamento contrário aos argumentos liberais (e do neoliberalismo) de que os fundamentos da liberdade e do individualismo justificam o mercado como regulador e distribuidor da riqueza e da renda. É desta corrente políticoeconômica (FRIEDMAN, 1984; SMITH, 2003) a ideia de que, na medida em que se potencializam as habilidades e a competitividade individuais, possibilita-se a busca ilimitada de ganho; portanto, o mercado seria produtor, por excelência, de bem-estar social. Esta argumentação é retomada e reforçada na atualidade para colocar em xeque o modo de organização social e política no que se refere à intervenção estatal (Estado social), para a produção de políticas públicas de bem-estar social.

Neste artigo, abordam-se as políticas de ações afirmativas para a Educação Superior na perspectiva de que estas são ações públicas para garantir direitos sociais. Portanto, implica que o Estado democrático de direito, no âmbito de sua responsabilidade, garanta igualdade na distribuição do conhecimento escolar ${ }^{1}$ como bem público.

\footnotetext{
${ }^{1}$ Segundo Enguita (2013), escolarizar a todas as crianças na educação fundamental nas mesmas condições é uma importante medida em termos de igualdade processual (formal), porém, é insuficiente porque a escola não produz resultados sozinha, mas em combinação com o meio familiar, social e com as características individuais de cada estudante. Disto decorre que a igualdade de oportunidade oferecida pelo Estado, por meio das condições iguais de partida, terá diferentes resultados na linha de chegada. O autor afirma que a resposta a este problema em torno da justiça escolar, ou seja, do modo de passar de iguais processos a iguais resultados tem sido dada pela ideia da igualdade de direitos positivos e o recurso às políticas compensatórias, de ações afirmativas.
} 


\subsection{A emergência do Estado moderno e seu papel na produção de bem-estar social}

O Estado, enquanto modelo regulatório que incorpora atribuições de bem-estar coletivo, teve sua gênese num tempo em que a tessitura da vida social passava por um processo de reavaliação e reconstrução, que conformaria uma nova forma de organização social: a sociedade capitalista. Todavia, pode-se dizer que a noção de Estado moderno converge com a orientação da democracia moderna (liberal burguesa) somente após a Revolução Industrial Inglesa (1776) e, principalmente, a Revolução Política Francesa (1789). Ao final do século XIX, afirma-se a materialização de um Estado moderno, de orientação contratualista, que fundirá duas diferentes concepções progressistas forjadas à época: a concepção do liberalismo econômico, que defendia a correlação entre propriedade e liberdade. O Estado deveria garantir a esfera das liberdades e a inviolabilidade da pessoa e da iniciativa privada em campo econômico. Já a concepção liberal democrática, baseada principalmente nas concepções de JeanJacques Rousseau e forjada com a Revolução Francesa, baseia-se na igualdade, mas essencialmente na igualdade jurídica; a soberania é do povo, que a expressa no Estado. Em ambas as noções, o ponto de partida e de chegada é sempre a liberdade e o benefício do indivíduo.

Para os contratualistas ${ }^{2}$, o Estado seria a concretização de um "Contrato Social" entre indivíduos que abrem mão de seus "direitos naturais de liberdade" em nome de uma regulação racional-legal (e simbólica!) exercida pelo poder estatal. O Estado moderno, baseado nessa concepção, passa a ser a instituição central na regulação das relações sociais, tendo a sua existência legitimada pelo "consentimento" da sociedade, constituindo-o em agente do monopólio legítimo da violência física (WEBER, 1991) bem como da violência simbólica (BOURDIEU, 2011).

Decorrente do processo histórico inerente à constituição da esfera pública moderna, prevalece ainda hoje, na organização política dominante, a ideia de Estado liberal que, desde sua gênese, visa a criar um paradigma sociopolítico que produza de maneira normal, constante e consistente, quatro bens públicos: legitimidade da governação, bem-estar econômico e social, segurança e identidade coletiva (SANTOS, 1999). Estes bens públicos só são realizáveis em conjunto: são, no

${ }^{2}$ Especialmente e apesar de apontarem pontos de vista diferentes, podem-se citar: Thomas Hobbes (1588-1679); John Locke (1631-1704); Jean-Jacques Rousseau (1712-1778) e Manuel Kant (1724-1804). 
fundo, bens diferentes, mas que precisam convergir para realizar o bem comum e a vontade geral sob o governo democrático.

É justamente dessa premissa que nasce toda a contradição da contratualidade moderna, pois, ao mesmo tempo em que traz como finalidade a maximização do bem comum e da vontade geral, sua base está marcada pelo pressuposto do individualismo. Se o indivíduo precede a sociedade, há como se estabelecer um vínculo social capaz de assegurar uma redistribuição equitativa de bens? Tal contradição torna-se explícita especialmente nos períodos de crise do sistema capitalista, quando a decisão política passa a ser fortemente influenciada pelo papel econômico dos Estados nacionais em detrimento de outras funções estatais.

Em relação à função de bem-estar social, pode-se afirmar que o Estado contemporâneo a incorpora, fortemente, no período que sucede o segundo grande conflito mundial do século $\mathrm{XX}^{3}$. Na época, ainda sob o efeito das carências materiais geradas pela guerra, eclodem as lutas por ampliação dos direitos, culminando com a emergência e a generalização do Estado de bem-estar social ${ }^{4}$, também conhecido como Estado providência, cujas atribuições de proteção social e de redistribuição de renda incorporavam, à noção de cidadania (MARSHALL, 1967), os direitos sociais de escopo universal. Contudo, essa função do Estado, efetivada nos países centrais, passa a ser subjugada por mais uma crise cíclica do sistema capitalista, iniciada no final dos anos 1970. As orientações sistêmicas passam a ser as de encolher os gastos dos Estados nacionais com as políticas de bem-estar social e incentivar a economia, dando mais liberdade para o mercado gerar riqueza e renda.

\footnotetext{
${ }^{3}$ Dribe (2004) entende Welfare State, no âmbito do Estado capitalista, como uma forma particular de regulação social que se expressa pela transformação das relações entre Estado e a Economia e entre Estado e a Sociedade, em um dado momento do desenvolvimento econômico. Tais transformações se manifestam na emergência de sistemas nacionais, públicos ou estatalmente regulados de educação, saúde, integração e substituição de renda, assistência social e habitação que, a par das políticas de salário e emprego, regulam direta ou indiretamente o volume, as taxas e o comportamento do emprego e salário da economia, afetando, portanto, o nível de vida da população trabalhadora. Trata-se de processos que, uma vez transformada a própria estrutura do Estado, expressam-se na organização e produção de bens e serviços coletivos, na montagem de esquemas e transferências sociais, na interferência pública sobre a estrutura de oportunidades de acesso a bens e serviços públicos e privados e, finalmente, na regulação da produção e de bens e serviços sociais privados. Com esta concepção, a autora situa a emergência de um Estado de bem-estar social no Brasil a partir da década de 30 do século XX, quando foram implantados sistemas nacionais para regular setores sociais da sociedade brasileira. Dentre estes, se pode citar a emergência do Ministério da Educação e Cultura.

${ }^{4}$ O estudo de Gosta Esping-Andersen, com base qualitativa, demonstra que os mais diferentes países de
capitalismo desenvolvido podem ser agrupados em três regimes básicos de bem-estar social: 1) o social-
democrata, exemplificado pelos países escandinavos, que se caracteriza pelo universalismo dos direitos
sociais e por uma importante redução no papel do mercado no âmbito do bem-estar social; 2 ) o conservador-
corporativo, exemplificado pela Alemanha e pela Itália, que se baseia nos direitos sociais, mas, perpetua uma
diferenciação social importante, envolvendo efeitos redistributivos mínimos; 3 ) o liberal, exemplificado pelos
Estados Unidos da América (EUA), Canadá e Inglaterra, que é dominado pela lógica do mercado (BATISTA, 2003).
} 
Castel (2000) considera que a incorporação de políticas de proteção social às atribuições do Estado é uma construção histórica que diz respeito ao papel social do próprio Estado. Ao longo do desenvolvimento do Estado contemporâneo, este incorporou, às formas do Estado de direito, os conteúdos do Estado social. Contudo, tal inserção se deu/dá ao custo de lutas sociais pelo acesso aos bens materiais, sociais e culturais da sociedade moderna. Por este motivo, afirma o autor, não parece apropriado utilizar o termo Estado-providência, com conotação mais assistencialista, mas Estado social geneticamente relacionado à luta por direitos. $\mathrm{O}$ Estado social, nesse sentido, pode ser entendido como uma das instâncias capazes de intervir para procurar resolver e/ou para exorcizar os riscos de descolamento, de ruptura do laço social, de exclusão ou de desintegração social que a falta de políticas de bem-estar social provocam. A função do Estado social é, conforme Castel (2000), essencialmente política, no sentido de que esta se inscreve no cerne das regulações das sociedades modernas para garantir sua coesão ${ }^{5}$ e deriva das múltiplas relações que se criaram entre Estado e complexo social, e dos seus efeitos históricos sobre a racionalidade interna do sistema político.

Enquanto efeito histórico da relação Estado e complexo social, à função redistributiva do Estado social, relaciona-se a definição de justiça social que as sociedades detêm sobre si. Nesse sentido, não se pode esquecer que está, subjacente à noção de justiça social, uma relação de poder. Com isto, se entende que as relações de dominação, em que um ator é dominante e o outro é dominado, não podem ser separadas das estruturas sociais como mediadoras ativas destas relações. No Estado social, as relações de poder podem ser difusas e dispersas, porém, isto não significa que não existam dominação e opressão entre os sujeitos-atores, já que atuam dentro da estrutura capitalista, inegavelmente hierárquica, que organiza as relações situando atores com maior poder do que outros.

\subsection{Justiça social e democracia: uma base ético-política para o Estado social}

Nas sociedades contemporâneas, a relação entre justiça social e poder está estritamente relacionada a questões de classe, etnia, raça e gênero. Nas questões de classe, grosso modo, no sentido marxista do termo, há, de um lado, uma classe dominante, e de outro, a classe dominada. A exploração exercida por uma classe

\footnotetext{
${ }^{5}$ O sentido de "coesão social" a que Castel (2000) se refere diz respeito à preocupação central de Émile Durkheim sobre a integração do indivíduo ao coletivo. A pergunta central que é colocada sob esta perspectiva é a seguinte: Quais são as responsabilidades do Estado, que papéis ele executa, que dificuldades ele encontra enquanto promotor da coesão social? São nestas questões que surgem os primeiros indícios do papel social do Estado moderno.
} 
social sobre outra gera a exclusão e o desejo de mudança social, cujo resultado é a rejeição à injustiça e a indignação diante das estruturas sociais que reproduzem a pobreza material. Nesta esfera de pensamento, a exploração apresenta-se como o resultado de uma assimetria social na qual alguns seres humanos lucram em detrimento de outros. Nesse sentido, a justiça social relaciona-se à distribuição de bens materiais.

Na concepção de Fraser (2001), que distingue injustiças materiais e injustiças culturais/simbólicas, às classes sociais o que interessa é a equalização do trabalho, das oportunidades, das condições sociais e de participação na vida pública; isto é, a redistribuição é a solução para seus problemas. Já para as injustiças culturais/ simbólicas, que inclui uma pluralidade de atores sociais, como homossexuais, mulheres, negros e minorias (e maiorias!) étnicas, as soluções para as demandas são de cunho afirmativo-valorativo, com a efetiva transformação de práticas cotidianas que perpetuam o preconceito e a discriminação ${ }^{6}$.

Há que se ressaltar, no entanto, que, nas relações sociais das sociedades capitalistas contemporâneas, as assimetrias sociais são dissimuladas e subterrâneas, e muitas vezes juridicamente negadas, já que o contrato social moderno afirma que perante a lei somos todos iguais. Dessa forma, as decisões e as ações na esfera pública são tratadas segundo a sua validade legal, seguindo regras e procedimentos que definem o que é justo, não significando que estas sejam "moralmente" justas. $\mathrm{Ou}$ seja, conforme diria Max Weber, se garantiria a impessoalidade e a neutralidade como a priori para a tomada de decisão nas instituições de Estado, garantindo a igualdade de acesso aos bens públicos prevista no sistema jurídico.

Contudo, é preciso atentar para o fato de que as decisões e ações de Estado não são neutras. Basta lembrar que o próprio exercício da função do Estado como provedor de bem-estar social é fruto de lutas sociais por melhores condições de vida. As ações e decisões do Estado são marcadas por projetos políticos cuja abrangência se dá, inclusive, no âmbito da elaboração de ideologias que penetram

\footnotetext{
${ }^{6}$ É importante ressaltar que Nancy Fraser elabora seu conceito de justiça social (bidimensional) a partir de uma reflexão sobre duas correntes de pensamento contemporâneo: John Rawls e Axel Honneth. Rawls propõe em sua obra "Uma teoria da justiça", um modelo de organização social e política liberal (contratualista), centrado na noção de justiça redistributiva. Para Rawls (2008), uma sociedade bem ordenada é aquela na qual existam mecanismos compensatórios e regulatórios legais capazes de diminuir as desigualdades econômicas e igualar as oportunidades de emprego. Já Honneth (2009), autor da obra Luta por reconhecimento, a gramática moral dos conflitos sociais, afirma que a questão central da justiça social não é a questão econômica, mas sim a do "reconhecimento". Considera, como sendo o centro da questão do reconhecimento, a noção de identidade. Para esse autor, a identidade de cada um é construída pela aceitação e pelo reconhecimento do outro, pois, se um grupo ou indivíduo não tem seu modo de ser respeitado pelo grupo hegemônico, vivencia, automaticamente, uma situação de injustiça.
} 
as crenças populares, produzindo e reproduzindo determinados modos de pensar e agir na sociedade. Não foi sem razão que Antonio Gramsci chamou a atenção para a assertiva de que o projeto político de esquerda devia adquirir a solidez das crenças populares, a fim de travar com êxito uma batalha pela hegemonia no seio da sociedade civil. Para esse pensador, aqueles que representam a antítese do projeto político capitalista deveriam sempre se lembrar de uma das proposições da "filosofia da práxis", que diz respeito ao argumento de que as crenças populares possuem a validade das forças materiais (GRAMSCI, 1986, p. 32).

Logo, por um lado, se pode opor à questão de que o Estado social é uma alternativa que não elimina os princípios da sociedade capitalista e, como tal, reproduz a cultura e a ideologia política deste sistema; portanto, sem uma mudança estrutural, não haverá justiça social. De outro lado, a renúncia ao Estado social na busca por uma mudança estrutural seria desconsiderar o fato de que existem, no âmbito dos Estados nacionais, classes e/ou grupos sociais historicamente excluídos do acesso aos bens culturais, econômicos e políticos, com necessidades imediatas. Para esses, a justiça social não pode esperar uma mudança estrutural, é preciso que haja uma intervenção imediata em sua realidade ${ }^{7}$.

Temos, assim, uma tensão que se coloca como dilema da modernidade: a necessidade de um projeto de sociedade que rompa com as estruturas sociais que reproduzem exclusão e desigualdade entre os seres humanos e a urgência da ação sobre esta mesma exclusão e desigualdade social. Para Fraser (2001), uma possível solução para este dilema seria entrelaçar princípios igualitaristas e diferencialistas. A autora propõe medidas afirmativas e transformativas. As medidas afirmativas atuariam sobre os resultados indesejados das injustiças sociais; contudo, não modificariam as estruturas que lhe deram origem; já as medidas transformativas visariam a alterar os resultados indesejáveis pela via da reestruturação institucional política e econômica em que se baseiam. Nessa

\footnotetext{
${ }^{7}$ É importante ressaltar que as políticas de ações afirmativas são ações públicas de cunho focal. Nesse sentido, seguem a argumentação de redistribuição de um bem para compensar uma desigualdade social empiricamente comprovada. A base da ação pública, nos países capitalistas ocidentais, para implantar políticas compensatórias tem sido fundamentada, em larga escala, na teoria da Justiça elaborada em 1971 por John Rawls, que propõe a noção de "justiça como equidade". Segundo o autor, a correção das injustiças sociais somente pode advir da prática de uma política visando à equidade, claramente localizada e pontual. Localiza-se o setor social menos favorecido (em razão de origem socioeconômica, raça, sexo, cultura ou religião) e mecanismos legislativos compensatórios entram em ação para buscar reparar, pela lei e com o consentimento geral, as injustiças cometidas. Porém, isso requer a suspensão temporária dos direitos de todos os demais, especialmente dos bem sucedidos, mas a equidade deve ser antes de tudo, reivindicada no tribunal da consciência e não somente nos tribunais comuns. Com os mecanismos compensatórios da ação pública, afirma Rawls, a sociedade avança gradativamente, não no sentido de uma igualdade absoluta, como é o desejo dos radicais socialistas, mas na direção da mais justa possível a ser alcançada dentro das normas de uma democracia moderna (RAWLS, 2008).
} 
perspectiva, a solução afirmativa à exploração por mecanismos de classe social seria o Estado de bem-estar social, ao passo que a solução transformativa se assentaria numa completa reestruturação das relações de produção ${ }^{8}$. Já no que se refere às injustiças simbólico-valorativas, o remédio afirmativo seria o multiculturalismo diferencialista e a solução transformadora consistiria na desconstrução de categorias como gênero e raça.

Inserindo-se nesta discussão, Santos $(1999,2000)$ considera que a proposta de gestão social da modernidade é a própria expressão de uma tensão dialética entre regulação social e emancipação social ${ }^{9}$, que se reproduz pela polarização constante entre a vontade individual e a vontade geral, entre o interesse particular e o bem comum. $\mathrm{O}$ autor entende que a ideia do contrato social e os seus princípios são o fundamento ideológico e político da contratualidade real, que organiza a sociabilidade e a política nas sociedades modernas.

A incapacidade de o Estado equilibrar regulação social e emancipação social tem implicado a rejeição da democracia procedimental e representativa em detrimento de uma democracia participativa consubstanciada pela participação dos cidadãos diretamente na construção da ação pública. Num espaço público em que agentes estatais convivem com interesses e organizações não estatais, cuja atuação coordena, este pode ser o ponto de partida da repolitização do Estado; isto é, a repolitização do Estado concebida nos marcos da nova organização política que coordena. Neste novo marco, o Estado é uma relação política parcelar e fraturada, aberta à competição entre agentes de subcontratação política, com concepções alternativas de bem comum e de bens públicos. Com essa percepção, o Estado, "[...] mais que uma materialidade institucional e burocrática, é um campo de luta política muito menos codificada e regulada que a luta política convencional." (SANTOS, 1999, p. 67).

\footnotetext{
${ }^{8}$ Fraser (2001), não defende um modelo distributivo liberal, mas uma via média entre as políticas socialistas transformadoras e as políticas reformistas liberais. Esta via média é chamada pela autora de "reforma não reformista".

9 "[...] como qualquer outro contrato, o contrato social assenta em critérios de inclusão que, portanto, são também critérios de exclusão. São três os critérios principais: o primeiro é que o contrato social inclui apenas indivíduos e suas associações. A natureza é excluída do contrato, e é significativo a este respeito que o que está antes ou fora dele se designe por estado de natureza. A única natureza que conta é a humana, e mesmo esta conta apenas para ser domesticada pelas Leis do Estado e pelas regras de convivência da sociedade civil. Toda outra natureza ou é ameaça ou é recurso. O segundo critério é o da cidadania territorialmente fundada. Só os cidadãos integram o contrato social. Todos os outros - sejam eles mulheres, estrangeiros, imigrantes, minorias (e, às vezes, maiorias) étnicas - são dele excluídos. Vivem no estado de natureza mesmo quando vivem na casa dos cidadãos. O terceiro critério é o do comércio público dos interesses. Só os interesses exprimíveis na sociedade civil são objeto do contrato. Estão, portanto, fora dele a vida privada, os interesses pessoais de que é feita a intimidade e o espaço doméstico." (SANTOS, 1999, p. 67).
} 
Nessas condições, o Estado, ao contrário do que parece, compromete-se ainda mais diretamente com critérios de inclusão e daí para a resolução das tensões existentes entre a diferença e a igualdade, caminhando pari passu para uma ação pública mediada pela redistribuição dos bens econômicos e o reconhecimento cultural/simbólico, conforme indica Fraser (2001). Por este motivo, a tensão entre democracia e capitalismo, que é urgente reconstruir, só poderá acontecer se a democracia for concebida como "democracia redistributiva", ressignificando, deste modo, as ações do Estado social. No sentido exposto, a democracia participativa é um princípio fundamental para a existência de justiça social.

[...] a democracia redistributiva tem de ser democracia participativa, e a participação democrática tem de incidir tanto na atuação estatal de coordenação como na atuação dos agentes privados, empresas, organizações não-governamentais cujos interesses e desempenho o Estado coordena. Em outras palavras, não faz sentido democratizar o Estado se, simultaneamente, não se democratizar a esfera não estatal. Só a convergência dos dois processos de democratização garante a (re) constituição do espaço público de deliberação democrática. (SANTOS, 1999, p. 68).

No atual estágio das tensões entre democracia e capitalismo, em que o Estado cada vez mais assume a função de coordenação do que de produção direta de bem-estar social, o controle da vinculação de recursos a destinações específicas pela via de mecanismos da democracia representativa torna-se virtualmente impossível; daí a necessidade de complementá-la com mecanismos de democracia participativa. A relativa maior passividade do Estado, decorrente da sua perda do monopólio regulatório, tem de ser compensada pela intensificação da cidadania ativa, sob pena de essa maior passividade ser ocupada e colonizada por "fascismos societais".

Assim, se para Gramsci (2000), a sociedade civil é a raiz ética do Estado, para Santos (1999), não basta democratizar o Estado para que a democracia se constitua em prática social; é preciso que todos os espaços estruturantes das relações sociais (público e privada) sejam democratizados. Pode-se dizer que, nesses argumentos, os autores se encontram, pois, se a sociedade civil é a raiz ética do Estado, é também esta que dá direção e sentido ao mesmo; portanto, se a sociedade não é democrática, também o Estado não o será. Com efeito, é desta mesma sociedade que emerge a noção de justiça social que a mesma tem de si.

Na esteira das reflexões inseridas, coloca-se a questão das políticas públicas de ações afirmativas para a Educação Superior no Brasil como uma necessidade 
urgente de intervenção na realidade educacional em favor de segmentos da sociedade que, por fatores relacionados à sua origem socioeconômica, étnica e racial, não tiveram/têm condições de acesso à Educação Superior. Trata-se de uma intervenção do Estado social que cumpre a sua responsabilidade de garantir a igualdade de oportunidades educacionais para todos os cidadãos do território nacional brasileiro.

O estudo de políticas públicas de corte social pode, acima de tudo, revelar a capacidade do Estado contemporâneo de cumprir com o seu papel de redistribuição do bem-estar coletivo. Contudo, a análise desse processo passa pela compreensão de que as políticas públicas são constructos sociais e locais (MULLER; SUREL, 2002), que resguardam especificidade social à ação pública. Logo, entende-se que toda política pública de corte social, resguardada pela especificidade local, atribui sentidos de justiça social na distribuição dos bens produzidos pelas sociedades humanas.

A análise que se segue busca explorar os impasses e disputas na construção das políticas de ações afirmativas para a Educação Superior na Universidade Federal do Rio Grande do Sul (UFRGS), em um momento específico desse processo: a avaliação dos objetivos do Programa, decorridos cinco anos de sua vigência, com vistas a estabelecer se os mesmos foram atingidos, bem como o seu impacto sobre os indicadores educacionais da Universidade.

\section{O CONSUN no processo de construção da política de ações afirmativas na UFRGS}

A Universidade Federal do Rio Grande do Sul (UFRGS-Brasil), com sede em Porto Alegre, capital do Rio Grande do Sul, foi instituída pelo Decreto n. ${ }^{\circ}$ 5.758, de 28 de novembro de 1934, e federalizada pela Lei . $^{\circ} 1.254$, de 04 de dezembro de 1950. É uma autarquia dotada de autonomia didático-científica, administrativa e de gestão financeira e patrimonial. Conforme o art. 2. ${ }^{\circ}$ do Estatuto do Conselho Universitário (UNIVERSIDADE FEDERAL DO RIO GRANDE DO SUL, 1995), a UFRGS, como universidade pública, é expressão da sociedade democrática e pluricultural, inspirada nos ideais de liberdade, de respeito pela diferença e de solidariedade, constituindo-se em instância necessária de consciência crítica, na qual a coletividade possa repensar suas formas de vida e suas organizações sociais, econômicas e políticas. O Conselho Universitário é o órgão máximo de tomada de decisões no âmbito da Universidade, ocupando funções normativas, 
deliberativas e de planejamento, tendo o Reitor como presidente e representação plural dos segmentos acadêmicos e da sociedade local.

\subsection{A política de ações afirmativas na UFRGS}

O processo de construção das políticas de ações afirmativas na UFRGS tem início em 2005, a partir de dois importantes movimentos: a criação do grupo de trabalho ações afirmativas, constituído por estudantes de diferentes cursos de graduação e docentes da Universidade. Os acadêmicos do grupo eram, em sua maioria, militantes de movimentos e organizações sociais vinculados à luta antirracista. No ano de 2006, o grupo de trabalho ações afirmativas tornou-se um projeto de extensão da Universidade. O segundo movimento, desencadeado pela reitoria em 2006, diz respeito à criação da Comissão Especial de Ações Afirmativas CEPE e do CONSUN, respectivamente, Conselho de Ensino e Pesquisa e Conselho Universitário, com o objetivo de elaborar uma proposta de ações afirmativas para a Universidade.

Depois de muitos impasses e negociações, o CONSUN, por meio da Decisão n. ${ }^{\circ} 134 / 2007$ (UNIVERSIDADE FEDERAL DO RIO GRANDE DO SUL, 2007), institui o programa de ações afirmativas da UFRGS (cotas sociais). O Programa define que $30 \%$ das vagas em cada curso seriam reservadas para candidatos egressos do sistema de ensino público de Ensino Fundamental e Ensino Médio. Do total das vagas reservadas, a metade $(15 \%)$ foi garantida para estudantes autodeclarados negros. Estabeleceu-se, ainda, a criação de dez vagas anuais para o ingresso de estudantes indígenas em cursos escolhidos pelas comunidades indígenas, a partir de discussão com a Universidade.

A política ficaria em vigor pelo período de cinco anos, com os seguintes objetivos a serem alcançados: i) ampliar o acesso em todos os cursos de graduação e cursos técnicos oferecidos pela UFRGS para candidatos egressos do sistema público de Ensino Fundamental e Ensino Médio, e para candidatos autodeclarados negros, egressos do sistema público de Ensino Fundamental e Ensino Médio, mediante habilitação de concurso vestibular e nos processos seletivos de cursos técnicos; ii) promover a diversidade étnico-racial e social no ambiente universitário; iii) apoiar estudantes, docentes e técnicos administrativos para que promovam, nos diferentes âmbitos da vida universitária, a educação das relações étnico-raciais; iv) desenvolver ações visando a apoiar a permanência, na Universidade, dos alunos referidos no art. 1. ${ }^{\circ}$ (estudantes egressos do sistema público de Ensino Fundamental e Ensino Médio, e estudantes autodeclarados negros egressos 
do sistema público de Ensino Fundamental e Ensino Médio, e estudantes indígenas), mediante condições de manutenção e de orientação para o adequado desenvolvimento e aprimoramento acadêmico-pedagógico.

A par da implantação da política, foram instituídas Comissões formadas por representantes da comunidade acadêmica e local: a Comissão de Implantação das ações afirmativas na Universidade; a Comissão de Acompanhamento dos alunos do programa de ações afirmativas; a Comissão de Acesso e Permanência indígena; a Comissão ad hoc à Comissão de Acompanhamento. Em 2012, com base nos dados e avaliações produzidas pelas Comissões, mais uma vez o CONSUN se reúne para discutir as políticas de ações afirmativas; desta vez, para avaliar se os objetivos da política foram atingidos, bem como verificar os seus impactos sobre os indicadores educacionais da Universidade ${ }^{10}$, e daí decidir sobre a necessidade de sua continuidade ou não.

O que se segue procura apontar - tendo como base empírica a 1.151. ${ }^{\mathrm{a}}$ sessão do CONSUN, realizada no dia 20 de julho de 2012 (UNIVERSIDADE FEDERAL DO RIO GRANDE DO SUL, 2012), consubstanciada por dois pedidos de parecer de vistas ao parecer de decisão da Comissão Especial de avaliação das ações afirmativas nomeada pela reitoria - as divergências de interesses, os conflitos e as disputas protagonizadas por segmentos do Conselho, a saber, dos docentes e dos discentes. A centralidade do debate se dá em torno da avaliação da Comissão Especial, que propunha a continuidade da política de ações afirmativas sem alterações significativas ao desenho original, colocado em prática pela Decisão n. ${ }^{\circ} 134 / 2007$ do CONSUN (UNIVERSIDADE FEDERAL DO RIO GRANDE DO SUL, 2007).

A proposta da Comissão Especial, segundo conselheiros dos segmentos discentes - Diretório Central dos Estudantes (DCE) da UFRGS e Associação de pósgraduandos (APG) da UFRGS, apoiados por conselheiros dos segmentos do Conselho de Ensino e Pesquisa (CEPE) e da Associação de Servidores da UFRGS (ASSUFRGS) -, desconsideraria todo o processo de aprendizagem social da política dos primeiros cinco anos de sua implantação.

\footnotetext{
${ }^{10}$ Foram produzidos documentos avaliativos relativos aos primeiros cinco anos da implantação das cotas sociais na UFRGS. São eles: o processo n. ${ }^{\circ}$ 23078-013633/07, que encaminha o resultado dos trabalhos da Comissão de Implantação das Ações Afirmativas na Universidade; relatório da Comissão de Acompanhamento dos Alunos do Programa de Ações Afirmativas 2008-2012; relatório da Comissão de Acesso e Permanência Indígena 2008-2012; relatório de Acompanhamento Quantitativo do ingresso de estudantes no âmbito da política de reserva de vagas no período 2008-2010, produzido pela Comissão ad hoc à Comissão de Acompanhamento.
} 


\subsection{A participação do CONSUN na construção das políticas de ações afirmativas na UFRGS}

No CONSUN, os confrontos, conflitos e contradições sobre as ações afirmativas aparecem no jogo de palavras oriundo das discussões plenárias, dos pareceres, dos pedidos de vistas, no período de avaliação da política. Cada segmento apresenta argumentações cuja linguagem expressa as condições sociais de produção do texto. O CONSUN, neste sentido, é um espaço de poder simbólico, que se traduz pela legitimidade dada à linguagem institucional de que cada um dos conselheiros é portador. Contudo, as falas de cada segmento do CONSUN expressam certa hierarquia, reconhecida no rito oficial da instituição. Algumas vozes estão mais autorizadas do que outras em situações solenes, como são as sessões do Conselho. Esta "autorização" é revestida de um poder simbólico que vem de fora, isto é, das condições sociais de produção e reprodução da fala, e não propriamente da manifestação linguística.

Tal proposição pode ser percebida no confronto de argumentos, nomeadamente, dos segmentos discentes (DCE e APG) apoiados por movimentos sociais, bem como por conselheiros da ASSURGS e do CEPE, com o segmento dos docentes e outros segmentos do Conselho na sessão para a avaliação da política de ações afirmativas em 2012. Dois pedidos de parecer de vistas, respectivamente, dos segmentos discente e docente ${ }^{11}$, à proposta de continuidade da política que foi apresentada ao CONSUN pela Comissão Especial de Avaliação da Política de Ações Afirmativas ${ }^{12}$ expressam as divergências e disputas em relação à política de ações afirmativas da UFRGS, em especial, na construção de sua argumentação sobre o que é "justo" para o acesso e a permanência de candidatos cotistas na Universidade, considerando-se que esta é uma política que visa a compensar uma desigualdade educacional verificada empiricamente.

Seguindo a perspectiva bourdiana, se considera que o argumento é fruto de uma construção linguística que representa as condições de sua instauração, o contexto social no qual este se instaura e, em particular, a estrutura do grupo em que se realiza.

\footnotetext{
${ }^{11}$ Ressalta-se, porém, que alguns conselheiros do segmento dos docentes, representado por docentes das várias unidades da UFRGS, apoiaram e votaram no parecer de vistas dos discentes. Esta informação é importante porque o parecer de vistas que se confrontou com o dos discentes foi elaborado e apoiado, especialmente, pelo segmento dos docentes do CONSUN.
}

${ }^{12}$ Designada por meio da Portaria n. ${ }^{\circ}$ 1.837/2012, assinada pelo Magnífico Reitor. 
Pode-se dizer que as condições de instauração da política de ações afirmativas na UFRGS expressam o próprio contexto da democratização do acesso à educação que emerge na década de 1980, quando os principais embates da sociedade brasileira convergiam para a luta pelo reconhecimento, na nova Carta Constitucional, do direito à educação como um direito social. Contudo, a defesa do direito à educação sempre esteve, em larga medida, relacionada à universalização da Educação Básica, corroborando com uma separação, quase injustificável, do ponto de vista dos direitos sociais, entre Educação Básica e Educação Superior. O termo 'educação básica', consubstanciado pela Carta Constitucional de 1988 e que passa a englobar a Educação Infantil, o Ensino Fundamental e o Ensino Médio, sempre foi tratado como um sistema à parte daquele que controla e organiza as Instituições de Ensino Superior (IES) (OLIVEIRA, 2001).

A evidência dessa assertiva pode ser identificada em duas leis que, durante o período do governo militar, operaram reformas no sistema educacional brasileiro: a Lei n. $^{\circ}$ 5.692, de 11 de agosto de 1971 (BRASIL, 1971), que fixou diretrizes para o Ensino de $1 .^{\circ}$ e $2 .^{\circ}$ Graus, e a Lei n. ${ }^{\circ} 5.540$, de 28 de novembro de 1968 (BRASIL, 1968), que reformou o Ensino Superior. Até a década de 1990, o Brasil conviveu com um ordenamento normativo próprio para cada um dos níveis de ensino. Já o ordenamento normativo nacional, que emerge a partir da Constituição Federal (CF) de 1988 (BRASIL, 1988) e da Lei de Diretrizes e Bases da Educação Nacional (LDBEN) n. ${ }^{\circ}$ 9.394, de 20 de dezembro de 1996 (BRASIL, 1996), traz uma perspectiva de unidade entre Educação Básica e Educação Superior; isto pode ser verificado no sentido do termo 'educação básica' que, como tal, coloca-se como base para o próximo nível: a Educação Superior.

Contudo, a separação entre Educação Básica e Educação Superior, na prática, ainda prevalece, restando à sociedade manifestar-se na busca pelo direito de acesso à Educação Superior e ao Estado brasileiro dar conta desta demanda social, principalmente porque a Educação Básica pública, atualmente direito público subjetivo dos quatro aos $17 \operatorname{anos}^{13}$, apresenta déficits no que diz respeito à qualidade do conhecimento necessário para a passagem ao nível da Educação

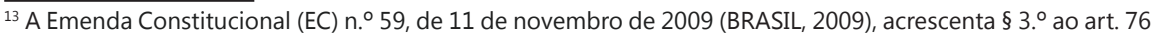
do Ato das Disposições Constitucionais Transitórias para reduzir, anualmente, a partir do exercício de 2009, o percentual da Desvinculação das Receitas da União incidente sobre os recursos destinados à manutenção e ao desenvolvimento do ensino de que trata o art. 212 da Constituição Federal, dá nova redação aos incisos I e VII do art. 208, de forma a prever a obrigatoriedade do ensino de quatro a 17 anos e ampliar a abrangência dos programas suplementares para todas as etapas da educação básica, e dá nova redação ao § $4 .^{\circ}$ do art. 211 , ao § $3 .^{\circ}$ do art. 212 e ao caput do art. 214, com a inserção neste dispositivo de inciso VI.
} 
Superior ${ }^{14}$. No primeiro quartil do século XXI, uma das respostas do Estado social brasileiro à demanda da sociedade por Educação Superior veio a ser dada por meio da implementação de políticas de ações afirmativas; mesmo que estas sejam medidas paliativas, já que se espera, com uma Educação Básica pública de qualidade, que o Estado garanta igualdade nas condições de acesso à Educação Superior para toda a cidadania nacional.

Já o contexto social no qual se instaura a política em tela está relacionado com a construção de relações sociais historicamente marcadas por uma cidadania tutelada, que inverte a lógica das relações entre cidadãos e Estado, instituindo uma cidadania nacional subserviente ao Estado como se este último não fosse uma criação da própria sociedade (BATISTA, 2013). Nesse escopo, o tratamento dado ao direito à educação ${ }^{15} \mathrm{e}$ às políticas educacionais tem sido marcado por representações sociais autoritárias, oriundas do processo de construção da esfera pública brasileira, cujo efeito social maior se verifica pelas insistentes práticas patrimonialistas - tendo sua maior expressão social pela não separação entre o bem público e o bem privado - e clientelistas - relações sociais e políticas baseadas na troca de favores entre "compadres" - na relação entre Estado e cidadãos (BATISTA, 2007).

Com base nessa tessitura social, persiste, no âmbito das políticas educacionais, um padrão de educação excludente e seletivo, que, frente ao século XXI, não atende ao direito à Educação Básica pública de qualidade para grande parte da população, requisito importante para o acesso ao nível da Educação Superior. Assim, os argumentos em confronto em torno da definição do que é "justo" para o acesso à Educação Superior no Brasil são a expressão, em alguma medida, de um contexto cultural e simbólico originado ainda nos tempos coloniais.

No que diz respeito à estrutura dos grupos em disputa por um modelo de justiça social no espaço do CONSUN, temos, de um lado, um segmento (dos docentes), cujo discurso traz a marca da fala oficial, da legitimidade institucional na qual

\footnotetext{
${ }^{14}$ Segundo Oliveira (2001), a luta pela universalização da educação básica sempre esteve apartada da defesa da democratização do ensino superior. Tal cisão parece obedecer a uma tradição, pois o que se observa na história da educação brasileira é o desenvolvimento das duas modalidades de ensino como dois sistemas distintos (BRASIL, 2009).

${ }^{15}$ A Constituição de 1824, que concretiza as normas para a instituição do Estado democrático de direito no Brasil, já propõe a educação como direito e a inviolabilidade dos direitos civis e políticos dos cidadãos brasileiros, porém sem alterar as estruturas da sociedade patrimonialista colonial. A regulamentação mantém intacto o sistema de produção escravagista (negros não são cidadãos, são mercadorias) e ainda a manutenção do domínio das relações patrimonialistas e clientelistas sobre os contingentes de homens livres e pobres. Cidadãos plenos em termo do gozo dos direitos foram considerados apenas poucos (AZEVEDO, 2004). Estes valores permeiam ainda hoje as representações sociais do cidadão brasileiro sobre as questões educacionais, tendo como efeito mais perverso a naturalização da desigualdade educacional.
} 
Quadro 1 - Construção dos Argumentos

\begin{tabular}{|c|c|}
\hline \multicolumn{2}{|r|}{ ARGUMENTO 1 - DISCENTES } \\
\hline DADOS & $\begin{array}{l}\text { A política de ações afirmativas na Universidade Federal do Rio Grande do } \\
\text { Sul tem ampliado o acesso de egressos de escolas públicas à Educação } \\
\text { Superior. } \\
\text { (Recorte do parecer de vistas da Comissão Especial de Avaliação da Política } \\
\text { de Ações Afirmativas) }\end{array}$ \\
\hline GARANTIA & $\begin{array}{l}\text { A) Por meio do Programa de Ações afirmativas, a Universidade conseguiu } \\
\text { ampliar o acesso em todos os seus cursos de graduação para candidatos } \\
\text { egressos das escolas públicas e para os candidatos egressos de escolas } \\
\text { públicas autodeclarados negros; B) A implementação do Programa e o } \\
\text { consequente ingresso de estudantes com perfis diferenciados levou a Uni- } \\
\text { versidade, em suas diferentes instâncias, tanto a uma maior reflexão sobre } \\
\text { a diversidade que caracteriza a sociedade quanto à promoção de maior } \\
\text { diversidade étnico-racial e social, e da educação das relações étnico-raciais } \\
\text { no ambiente universitário; C) A análise do desempenho acadêmico dos es- } \\
\text { tudantes justifica a instituição da política de reserva de vagas e sinaliza para } \\
\text { a necessidade de seu aperfeiçoamento no sentido de qualificar a permanên- } \\
\text { cia e o desempenho (Recorte do parecer da Comissão Especial de Avaliação } \\
\text { da Política de Ações Afirmativas) }\end{array}$ \\
\hline APOIO & $\begin{array}{l}\text { Tanto nos dados informados pela Comissão Especial quanto nas avaliações } \\
\text { feitas pelos mais diversos órgãos consultados, em especial os relatórios das } \\
\text { Comissões e a legislação, chega-se a conclusões positivas que reafirmam a } \\
\text { necessidade de manutenção do Programa de Ações Afirmativas na UFRGS. } \\
\text { (Parecer de vistas dos segmentos discentes) }\end{array}$ \\
\hline PROPOSIÇÃO & $\begin{array}{l}\text { A Universidade necessita aprimorar o Programa, adequando-se à realidade } \\
\text { dos estudantes cotistas por meio da desvinculação entre cotas sociais e } \\
\text { étnico-raciais; da ampliação do percentual de reserva de vagas para egres- } \\
\text { sos de escolas públicas (cotas sociais e étnico-raciais) de } 30 \% \text { para } 50 \% \text {; } \\
\text { da criação e adoção de medidas que visem a propiciar a permanência dos } \\
\text { estudantes cotistas na universidade; do aperfeiçoamento das ações de } \\
\text { acompanhamento dos acadêmicos cotistas; da modificação da forma de } \\
\text { ingresso dos estudantes cotistas aprovados no vestibular. } \\
\text { (Parecer de vistas dos segmentos discentes) }\end{array}$ \\
\hline REFUTAÇÃO & $\begin{array}{l}\text { Por outro lado, a função atribuída à Comissão Especial não foi cumprida em } \\
\text { sua totalidade e assim seu parecer não expressa as conclusões e delibera- } \\
\text { ções que advêm dos materiais que foram utilizados. As finalidades expres- } \\
\text { sas pela Comissão visavam a uma avaliação do Programa de Ações Afirma- } \\
\text { tivas da UFRGS que fornecesse instrumentos e subsídios para o momento } \\
\text { de definição da continuidade do Programa. Porém, a avaliação deve levar } \\
\text { em conta não apenas a comparação entre a realidade universitária antes e } \\
\text { depois do Programa, mas tambemm uma continuidade que permita a crítica } \\
\text { ao que foi originalmente implementado e sua melhoria dentro do mesmo } \\
\text { espírito que norteou as decisões do Conselho. } \\
\text { (Parecer de vistas dos segmentos discentes). }\end{array}$ \\
\hline
\end{tabular}

Fonte: Elaborado pela autora com base em Liakopoulos (2002). 
Quadro 1 - Continuação...

\begin{tabular}{|l|l|}
\hline \multicolumn{1}{|c|}{ ARGUMENTO 2 - DOCENTES } \\
\hline DADOS & $\begin{array}{l}\text { Fica instituído o Programa de Ações Afirmativas, através de Ingresso de } \\
\text { Reserva de Vagas para acesso a todos os cursos de graduação da Univer- } \\
\text { sidade Federal do Rio Grande do Sul - UFRGS, de candidatos egressos do } \\
\text { Sistema Público de Ensino Fundamental e Médio e de candidatos egressos } \\
\text { do Sistema Público de Ensino Fundamental e Médio autodeclarados negros } \\
\text { e candidatos indígenas. } \\
\text { (Recorte do parecer da Comissão Especial de Avaliação da Política de Ações } \\
\text { Afirmativas) }\end{array}$ \\
\hline GARANTIA & $\begin{array}{l}\text { Estimular a qualificação, o aperfeiçoamento e a valorização do Ensino } \\
\text { Público Fundamental e Médio através de políticas de estímulo ao acesso ao } \\
\text { Ensino Superior Público de excelência de egressos desse sistema de ensino. } \\
\text { (Recorte do parecer da Comissão Especial de Avaliação da Política de Ações } \\
\text { Afirmativas). }\end{array}$ \\
\hline APOIO & $\begin{array}{l}\text { Os signatários do presente parecer, após discussões realizadas com o o } \\
\text { propósito de obter consenso quanto a sugestões para o aperfeiçoamento } \\
\text { da proposta apresentada pela Comissão Especial, encaminham o texto a } \\
\text { seguir que tencionou, antes de tudo, preservar parte substancial do trab- } \\
\text { alho efetuado pela Comissão. } \\
\text { (Parecer do segmento dos docentes). }\end{array}$ \\
\hline PROPOSIÇÃOO & $\begin{array}{l}\text { Com o intuito de contribuir para um melhor encaminhamento da discussão } \\
\text { pelo Plenário do CONSUN, optou-se por oferecer a proposta da decisão no } \\
\text { formato integral do parecer (com sugestões de mudanças ou acréscimos) } \\
\text { elaborado pela Comissão Especial (Parecer do segmento dos docentes). }\end{array}$ \\
\hline
\end{tabular}

Fonte: Elaborado pela autora com base em Liakopoulos (2002).

a ciência encontra-se inevitavelmente engajada. Certamente, tal grupo ocupa lugar confortável na arena de debates, já que se considerarmos que as diferentes estratégias da luta simbólica de todos os dias, mais ou menos ritualizadas, assim como os enfrentamentos de visões e de previsões da luta propriamente política, encerram certa pretensão à autoridade simbólica enquanto poder socialmente reconhecido de impor certa visão do mundo social, isto é, das divisões do mundo social (BOURDIEU, 1996).

Por outro lado, os segmentos dos discentes, mesmo que participem dos rituais coletivos de nomeação e tenham legitimidade frente aos seus pares, por não carregarem vínculo formal com a organização institucional, são pouco reconhecidos em sua autoridade para propor mudanças nos ritos institucionais e, em decorrência, nas matérias das sessões do CONSUN. Assim, reconhece-se que, em meio à luta pela imposição da visão legítima, os agentes detêm um poder proporcional ao seu capital simbólico, ou seja, ao reconhecimento que recebem de um grupo: a autoridade que funda a eficácia performativa do discurso é um percipi, um ser conhecido e reconhecido, que permite impor um percipere, ou melhor, de impor como se estivesse impondo oficialmente, perante todos e em 
nome de todos, o consenso sobre o sentido do mundo social que funda o senso comum (BOURDIEU, 1996).

\subsection{Ações Afirmativas na UFRGS: confrontos e disputas no CONSUN}

O Quadro 1, baseado em Liakopoulos (2002), apresenta os argumentos dos segmentos dos discentes (DCE e APG) e do segmento dos docentes, com o objetivo de apontar sua consistência retórica quanto à noção de justiça social, conforme discussão realizada na seção dois. É importante ressaltar que os argumentos analisados no Quadro 1 foram construídos visando a emitir parecer de vistas ao parecer da Comissão Especial de Avaliação da Política de Ações Afirmativas, em um contexto de tomada de decisões do Conselho sobre os rumos da política de ações afirmativas da UFRGS, que completava cinco anos e passava por avaliação.

Conforme se pode perceber, tanto o Argumento 1 quanto o Argumento 2 desenvolvem a sua base argumentativa a partir de um texto comum: o parecer da Comissão Especial de Avaliação da Política de Ações Afirmativas da UFRGS. Contudo, a construção da argumentação apresenta diferentes escolhas de abordagem dos conteúdos do citado texto, já que há divergências político-conceituais entre os dois argumentos sobre a política de ações afirmativas da UFRGS, bem como sobre o parecer da Comissão Especial.

Analisando-se o Quadro 1, verifica-se que, na construção dos Argumentos 1 e 2 , há diferentes escolhas de conteúdos para representar as categorias elencadas como constitutivas de uma argumentação que pretendia "convencer" um determinado público, os conselheiros do CONSUN, para uma questão em debate - as políticas de Ações Afirmativas, cuja especificidade exigia a explicitação de um modelo de justiça social. Percebe-se que a Argumentação 1 (dos segmentos dos discentes) segue uma linha de contraponto ao parecer da Comissão Especial; já o argumento 2 (do segmento dos docentes) segue uma linha de adesão ao citado parecer. Tais posicionamentos já demonstram que há uma disputa para determinar o que é "justo" sobre uma proposta estabelecida oficialmente, visto que é consenso entre todos os segmentos do Conselho o fato de que o programa de Ações Afirmativas deve ter continuidade.

No Argumento 1, identifica-se, na categoria "proposição", uma proposta cujo conteúdo resulta, segundo os segmentos dos discentes informam, em Ata da 


\section{$1.151^{\mathrm{a}}$ sessão do CONSUN (UNIVERSIDADE FEDERAL DO RIO GRANDE} DO SUL, 2012), de todo um processo de construção da política em seus diversos espaços e diversidade de atores, o que não foi considerado no parecer da Comissão Especial. Na ocasião da $1.151^{\mathrm{a}}$ sessão para a discussão do parecer da Comissão Especial, os segmentos discentes distribuíram uma carta intitulada "Por que os representantes discentes não assinaram a proposta de alteração da Decisão $n$. 134/2007 encaminhada pela Comissão Especial de avaliação da Política de Ações Afirmativas". Na Ata (1151/2012) dessa sessão, consta o seguinte depoimento dos discentes:

Deve-se atentar que se nossa discordância fosse restrita ao conteúdo da proposta encaminhada, nossa manifestação se daria apenas por um pedido de vistas. Todavia, justificamos nossa não assinatura por uma questão de método, pelo respeito a valores de democracia e representatividade, valores largamente desrespeitados pela administração central e seus representantes na Comissão Especial (o presidente e o vice-presidente). A proposta que chega ao plenário não é resultado de meses de trabalho da Comissão Especial, mas, sim, de uma negociação entre o presidente e o vice-presidente da Comissão com os Diretores de Unidades. (UNIVERSIDADE FEDERAL DO RIO GRANDE DO SUL, 2012, p. 4).

A partir dessa manifestação plenária, os segmentos dos discentes apresentam o seu parecer de vistas à proposta da Comissão Especial. Para sustentar as proposições da sua argumentação, os segmentos discentes trazem, como "apoio", as conclusões positivas de estudos que confirmam a necessidade de continuidade da política de ações afirmativas na UFRGS. Nesse sentido, também os "dados" e a "garantia" corroboram com as proposições, apresentando o efeito dos estudos e da legislação que têm apoiado as políticas públicas de ações afirmativas para o acesso à Educação Superior. Diante desta construção argumentativa, os segmentos dos discentes apresentam novas proposições para a continuidade da política de ações afirmativas na UFRGS, refutando o parecer da Comissão Especial. Nesse caso, as categorias "dados", "garantia" e "apoio" são elencadas no sentido de reforçar a sua proposição e, com isto, refutar o argumento oficial.

Já o Argumento 2 seleciona diferentes conteúdos do mesmo texto para compor suas categorias argumentativas. Apresenta "proposição", que vai ao encontro do parecer da Comissão Especial. Desta forma, os conteúdos selecionados para as 
categorias "dados", "apoio" e "garantia" são bastante gerais, remetendo para a perspectiva consensuada da política de ações afirmativas da UFRGS, na Decisão n. ${ }^{\circ}$ 134/2007. Nesse argumento, não há refutação do argumento oficial: há uma opção pela continuidade do programa de Ações Afirmativas, em conformidade com o parecer da Comissão Especial, bem como com o que fora pactuado na Decisão n. ${ }^{\circ} 134 / 2007$ do CONSUN.

Já no que se refere à continuidade do Programa, com concordância compartilhada por todos os segmentos do Conselho, é possível observar que a Comissão Especial utiliza a mesma justificativa que fora apresentada na Decisão n. ${ }^{\circ}$ 134/2007.

[...] as medidas compensatórias são uma modalidade de política pública assumida pelo Estado para minimizar/eliminar as consequências que a própria intervenção do Estado produziu, na efetivação e na persistência de profundas, comprovadas e constrangedoras desigualdades étnicas, no Brasil. (UNIVERSIDADE FEDERAL DO RIO GRANDE DO SUL, 2007, p. 5).

Na decisão n. ${ }^{\circ}$ 134/2007, reproduzida pela Comissão Especial em 2012, salienta-se que a emergência de políticas de ações afirmativas se dá quando há uma urgência em minimizar os efeitos de condições históricas sobre determinados segmentos da população; nesse caso, de negros e indígenas. Contudo, a justificativa da Decisão n. ${ }^{0} 134 / 2007$ não faz referência aos brancos pobres que, mesmo não sofrendo as consequências da exclusão cultural e simbólica, sofrem as consequências da exclusão social, devido às condições socioeconômicas às quais estão submetidos.

Tal ausência pode estar relacionada ao fato de que, no Brasil, a desigualdade social - ocasionada tanto pela origem étnico-racial quanto socioeconômica - é um fenômeno coletivo, que persiste; portanto, minimizar o efeito da origem socioeconômica como fator importante para o acesso à etapa da Educação Superior pode ser visto como uma estratégia política que dilui a discussão sobre as políticas de ações afirmativas à herança histórico-cultural do preconceito étnico-racial; incluir a origem socioeconômica como fator que exerce influência nas condições de acesso à Educação Superior significaria aumentar, em muito, a população a ser atendida por ações públicas compensatórias.

Com efeito, o aprofundamento da discussão sobre a qualidade da oferta da Educação Básica pública como um dos fatores que têm impactado nas condições de acesso ao nível da Educação Superior permitiria ir muito além de ações públicas 
paliativas, como são as políticas de ações afirmativas. Tal impacto das políticas compensatórias sobre políticas universalizadas, como é o caso da Educação Básica, levadas a cabo, induziria o Estado social, seguindo as indicações de Fraser (2001), a uma reforma estrutural da educação no Brasil.

A contradição da justificativa para a implantação da política de ações afirmativas da UFRGS (UNIVERSIDADE FEDERAL DO RIO GRANDE DO SUL, 2007), reafirmada pela Comissão Especial em 2012 (UNIVERSIDADE FEDERAL DO RIO GRANDE DO SUL, 2012), está justamente no fato de que, ao se estabelecerem os critérios de acesso por meio da reserva de vagas, prevaleceram os de origem escolar (escola pública) e renda familiar, independentemente da origem étnicoracial, especificamente no caso dos negros. A proposição dos segmentos dos discentes (cf. Quadro 1) remete especialmente a essa contradição, inferindo sobre a necessidade de separação entre cotas sociais (com critérios de origem escolar e socioeconômica) e cotas raciais, cujo critério deveria residir especificamente sobre a origem étnico-racial, com o reconhecimento de que o preconceito racial excluiu, historicamente, os negros do acesso à Educação Superior.

Ainda na justificativa da Decisão n. ${ }^{\circ}$ 134/2007, considera-se que:

[...] as ações compensatórias não têm o poder de resolver problemas históricos nem de substituir outras políticas públicas fundamentais, mas de compensar, a curto prazo, uma geração, a partir do reconhecimento público do problema social. As políticas de ações afirmativas, nesse sentido, caracterizam-se como emergenciais tendo como objetivo atingir uma geração de jovens que não serão beneficiados pelas reformas educacionais do porvir ou, mesmo, em andamento. (UNIVERSIDADE FEDERAL DO RIO GRANDE DO SUL, 2007, p. 5).

Nesse fragmento da justificativa, percebe-se, por um lado, o caráter paliativo e emergencial da política, ao prever-se que a oferta é para compensar jovens que, por razões históricas, foram excluídos da Educação Superior. Por outro lado, porém, afirma que o objetivo da política é ofertar oportunidade educacional a jovens que não serão beneficiados por reformas educacionais substanciais, cujo efeito resultasse no fim da exclusão étnico-racial. Mais uma vez, a justificativa reforça o caráter de reparação de uma exclusão étnico-racial histórica do acesso à Educação Superior, eximindo-se de justificar a exclusão socioeconômica (que leva negros, índios e brancos a frequentarem escola pública) como um fator 
que também influencia nas condições de acesso, mesmo que se reconheça que a exclusão étnico-racial resulte em exclusão socioeconômica e social. Resta ainda observar, na justificativa da Decisão n. ${ }^{\circ}$ 134/2007, a existência de uma negatividade discursiva no que se refere a uma perspectiva de mudança oriunda de políticas públicas educacionais que resultem no fim da exclusão étnico-racial e, daí, do acesso à Educação Superior.

É importante ainda considerar que a base das considerações postas como justificativa para a implantação das políticas de ações afirmativas da UFRGS, na Decisão n. ${ }^{\circ} 134 / 2007$, é fruto de uma construção que incluiu a comunidade acadêmica e local. Percebe-se, nesse sentido, que houve um consenso social que dá legitimidade à política. Contudo, ainda há muito a ser aprendido com a implantação dessa política na UFRGS em termos de construção de um modelo de justiça social que lhe dê suporte.

O modelo bidimensional de justiça social apontado por Fraser (2001) propõe compreender e distinguir injustiça socioeconômica e injustiça cultural ou simbólica, uma vez que ambas estão enraizadas e imbricadas na sociedade contemporânea. Para a autora, a injustiça socioeconômica baseada na exploração do trabalho, na marginalização e na privação econômica se resolveria pela "redistribuição" no âmbito do Estado social; já a injustiça cultural ou simbólica, alicerçada na dominação cultural, no não reconhecimento, na invisibilização e no desrespeito de uma cultura se resolveria pelo "reconhecimento", no âmbito de políticas multiculturais. Nessa perspectiva, pode-se formular um projeto de justiça social, propondo soluções ético-políticas através dos recursos do "reconhecimento" e da "redistribuição", ambos se sustentando e se fortalecendo para sanar os problemas referentes à desigualdade educacional na Educação Superior no Brasil.

O que se pode perceber nos documentos ora analisados é que a política de ações afirmativas da UFRGS apresenta justificativa, dada pela Decisão n. ${ }^{\circ}$ 134/2007, que aponta para uma referência de justiça social com alguma proximidade da perspectiva cultural/simbólica (status); porém, o texto não aponta, explicitamente, o peso do fator socioeconômico (classe) para o acesso ao nível da educação superior, em especial, em IES públicas brasileiras. Já no que se refere aos argumentos dos segmentos dos discentes e dos docentes, observa-se que os docentes seguem a perspectiva de justiça dada pela Comissão Especial, que adota o argumento do Programa formulado em 2007. Os segmentos dos discentes, por sua vez, propõem uma perspectiva de justiça social cuja proximidade com a dimensão do "reconhecimento" exige ir além do modelo proposto em 2007, já 
que infere sobre a necessidade da separação entre cotas sociais e cotas raciais, e sobre a não consideração de critérios de origem escolar e de renda para o caso das cotas raciais.

Contudo, no conteúdo da argumentação do texto da política, na Decisão n. ${ }^{\circ}$ 134/2007, prevalece um modelo de justiça social unidimensional, voltado para a dimensão cultural da desigualdade social dos cotistas frente à Educação Superior. Já os segmentos dos discentes reafirmam o modelo de justiça social na mesma perspectiva da Decisão n. ${ }^{\circ}$ 134/2007, porém, para tal, postulam a separação entre cotas sociais e cotas raciais, no intuito de garantir o reconhecimento da desigualdade étnico-racial. Nesse sentido, em nenhum dos argumentos em disputa há uma proposição de um modelo de justiça social bidimensional, isto é, que incorpore "o reconhecimento" (status) e a "redistribuição" (classe).

Finalmente, se pode inferir que a reflexão sobre as políticas de ações afirmativas como forma de acesso à Educação Superior constitui-se em momento ímpar para a abordagem crítica sobre a qualidade do conhecimento ofertado na Educação Básica pelas escolas públicas, frequentadas pela maior parte da população de crianças, adolescentes e jovens brasileiros, e sua relação com as condições de acesso ao nível da Educação Superior, em especial, a Educação Superior pública. Essa discussão, porém, não está presente em nenhum dos documentos analisados neste artigo.

Já o CONSUN, enquanto espaço de poder no campo acadêmico, dá direção e sentido às políticas de ações afirmativas no âmbito da Universidade. Essa característica faz desse órgão, através da representação de segmentos sociais, uma arena de disputas por modelos de justiça social para a Educação Superior. Todavia, o acesso aos instrumentos legítimos de expressão e, portanto, a participação no quinhão da autoridade institucional, organiza-se a partir de uma hierarquia institucional cujo resultado, quase sempre, resulta em desigualdade na representação de segmentos nos atos decisórios. Conforme Bourdieu (1996), a matéria do discurso depende da posição social do locutor que, por sua vez, comanda o acesso que se lhe abre à língua da instituição, à palavra oficial e legítima. 
Na $1.151^{\text {a }}$ sessão do CONSUN, realizada em 2012, que teve como principal matéria a discussão dos dois pareceres de vista ao parecer da Comissão Especial de avaliação das políticas de ações afirmativas, houve impasses, confrontos e discussões, porém, a decisão da maioria do colegiado apoiou o parecer de vistas do segmento dos docentes. Isto significou que não houve desvinculação entre cotas raciais e cotas sociais - as cotas raciais seguem submetidas a critérios de origem escolar e socioeconômicos; não houve ampliação do percentual de reserva de vagas para estudantes egressos de escolas públicas de $30 \%$ para $50 \%{ }^{16}$; não se normatizou uma política específica de permanência para os estudantes cotistas na Universidade; não houve modificação na forma de ingresso dos cotistas na Universidade. Assim, as "proposições" dos segmentos dos discentes foram sendo derrotadas, em sua grande maioria, voto a voto, até que prevalecesse a vontade oficial.

\section{Considerações finais}

O presente trabalho pretendeu, mesmo que de forma sintética, problematizar e discutir questões conceituais e empíricas sobre o tema das políticas públicas de ações afirmativas para a Educação Superior no Brasil, com recorte especial à implantação de tais políticas na Universidade Federal do Rio Grande do Sul. Na digressão, se procurou discutir questões relacionadas ao Estado social enquanto provedor de políticas públicas de corte social em suas intersecções com os conceitos de justiça social e democracia, enquanto base ético-política da ação pública.

Com vistas nesse referencial, se procurou analisar os principais impasses, conflitos e contradições da política de ações afirmativas da UFRGS na $1.151^{\mathrm{a}}$ sessão do Conselho Universitário realizada em 2012, com o objetivo de avaliar os primeiros cinco anos da implantação da política. Buscava-se compreender qual era a noção de justiça social construída pelos segmentos do Conselho e que davam base à política de ações afirmativas da UFRGS, pressupondo, é claro, que toda ação pública afirmativa é mediada por um sentido de justiça social.

A análise dos documentos apontou que, na sessão do CONSUN destinada à avaliação das políticas de ações afirmativas, houve um confronto de argumentos

\footnotetext{
${ }^{16}$ Logo após a Decisão do Conselho, o Decreto n. ${ }^{\circ} 7.824$ de 11 de outubro de 2012 (BRASIL, 2012a) regulamenta a Lei n. ${ }^{\circ} 12.711$ de 29 de agosto de 2012 - Lei de cotas - (BRASIL, 2012b), que destina 50\% das vagas em universidades e institutos federais para estudantes egressos de escolas públicas. O CONSUN, com base no ordenamento legal federal, passa, paulatinamente, a implementar os $50 \%$ de reserva de vagas para estudantes de escolas públicas e estudantes de escolas públicas autodeclarados negros.
} 
entre dois segmentos, a saber, dos discentes e dos docentes. O cerne da discussão entre os dois segmentos girou em torno da questão relativa à reserva de vagas para candidatos autodeclarados negros (cotas raciais versus cotas sociais). Ao final, a análise demonstra os conflitos e contradições entre segmentos do Conselho para decidir o que é "justo" para a definição das normas de acesso (e permanência) à Universidade por meio das ações afirmativas da UFRGS.

Considerando-se a referência de justiça social bidimensional apontada por Fraser (2001), predomina, nas ações afirmativas da UFRGS - ainda que não aponte em sua argumentação textual o peso do fator socioeconômico para o acesso à Educação Superior e ressalte as questões étnico-raciais - um modelo de justiça social unidimensional, com foco na dimensão socioeconômica, que dá ênfase a critérios de acesso por origem escolar e renda familiar em detrimento da origem étnico-racial do candidato. Contudo, pode-se inferir que as discussões plenárias sobre os critérios de acesso e permanência dos cotistas na Universidade - sobretudo, por conta da pressão dos segmentos, em especial, dos discentes - seguirão na pauta do CONSUN, podendo, com a aprendizagem da política, encaminhar-se para um modelo de justiça social bidimensional, isto é, que incorpore, na política em tela, critérios socioeconômicos (classe) e culturais (status).

Tal perspectiva pode ser observada, igualmente, no âmbito do ordenamento jurídico e normativo federal. Com o objetivo de reduzir a desigualdade educacional na Educação Superior brasileira, à medida que as IES públicas vão implantando ações afirmativas, inicia-se, em âmbito nacional, a construção da sua justiciabilidade ${ }^{17}$. Produz-se uma legislação que resulta em normatização das novas regras para o acesso -e permanência - à Educação Superior pública em todo o país. Este ordenamento jurídico e normativo incorpora o debate da sociedade e tem seu auge com o Decreto $n .^{\circ} 7.824 / 2012$ (BRASIL, 2012a), que regulamenta a Lei n. ${ }^{\circ}$ 12.711/2012 (Lei de cotas) (BRASIL, 2012b), que destina 50\% das vagas em universidades e institutos federais para estudantes oriundos de escolas públicas, considerando critérios como origem escolar (escola pública), renda familiar e raça. Logo, o cenário jurídico indica que há uma tendência na construção da justiciabilidade das políticas de ações afirmativas para a Educação Superior no Brasil, cujo sentido de justiça social aproxima-se da noção bidimensional.

Resta ainda ressaltar o fato de que, nos documentos analisados neste artigo, observou-se a ausência da discussão sobre a influência da qualidade do conhecimento

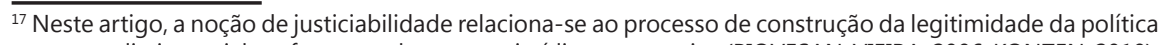
enquanto direito social em face ao ordenamento jurídico e normativo (PIOVESAN; VIEIRA, 2006; KONZEN, 2010). 
ofertado na Educação Básica pública como elemento importante para o acesso ao nível da Educação Superior no Brasil, em especial nas IES públicas. Pesquisas (SOUZA, 2009; GRISA, 2009) têm apontado, persistentemente, que as vagas para Educação Superior em IES públicas têm sido "reservadas" para candidatos que tenham cursado a Educação Básica em escolas privadas. A naturalização da desigualdade educacional gerou uma estratificação social que pode ser percebida pela ascensão de classes e/ou grupos sociais privilegiados que, por gerações, tem ocupado os postos de maior reconhecimento social e econômico na organização do trabalho na sociedade capitalista brasileira.

Finalmente, a título de considerações gerais, pode-se dizer que a sociedade brasileira parece acordar para a realidade que a expõe enquanto Nação, que tem uma dívida histórica com aqueles cidadãos que ficaram (ficam) à margem de seus direitos. O momento de reflexão é bem-vindo. Afinal, Max Weber (1991), ao situar seu conceito de classe social, já afirmava que apenas quando a situação de classe é percebida não como um fato natural e tendencialmente imutável é que podemos falar na possibilidade de uma articulação política visando à superação desta condição.

\section{Referências}

AKKARI, A. J. Desigualdades educativas estruturais no Brasil: entre Estado, privatização e descentralização. Educação \& Sociedade, São Paulo, v. 22, n. 74, p. 163-189, abr. 2001.

ALMEIDA, A. M. F.; NOGUEIRA, M. A. (Org.). A escolarização das elites: um panorama internacional da pesquisa. Petrópolis: Vozes, 2002.

AZEVEDO, J. M. L. O Estado, a política educacional e a regulação do setor da educação no Brasil: uma abordagem histórica. In: FERREIRA, N. S. C.; AGUIAR, M. A. S. (Org.). Gestão da Educação: impasses, perspectivas e compromissos. São Paulo: Cortez, 2004. p. 17-42.

BARBOSA, M. L. O. Desigualdade e desempenho: uma introdução à sociologia da escola brasileira. Belo Horizonte: Argvmentvm, 2009.

BARROZO, P. D. A ideia de igualdade e as ações afirmativas. Lua Nova, São Paulo, n. 63, p. 103-141, 2004. 
BATISTA, N. C. Gestão de políticas públicas educacionais no âmbito local: o desafio dos conselhos municipais de educação. Ver a Educação, Belém, v. 9, n. 1, p. 135-137, 2003.

A formação do Estado nacional brasileiro: implicação para a gestão das políticas públicas educacionais. Eccos, São Paulo, v. 9, n. 2, p. 369-386, jul./dez. 2007.

. Políticas públicas para a gestão democrática da educação básica: um estudo do Programa Nacional de Formação de Conselheiros Municipais de Educação. Jundiaí: Paco Editorial, 2013.

BOURDIEU, P. A economia das trocas linguísticas. São Paulo: EDUSP, 1996.

. Espíritus de Estado: gênese e estrutura do campo burocrático. In: $\overline{R a z o ̃ e s}$ práticas: sobre a teoria da ação. 11. ed. Campinas: Papirus, 2011.

BRASIL. Lei $n^{\circ} 5.540$, de 28 de novembro de 1968. Fixa normas de organização e funcionamento do ensino superior e sua articulação com a escola média, e dá outras providências. Diário Oficial [da] República Federativa do Brasil, Brasília, DF, 23 nov. 1968.

. Lei $n^{\circ} 5.692$, de 11 de agosto de 1971. Fixa diretrizes e bases para o ensino de $1^{\circ}$ e $2^{\circ}$ graus, e dá outras providências. Diário Oficial [da] República Federativa do Brasil, Brasília, DF, 12 ago. 1971.

. Constituição da República Federativa do Brasil de 1988. Diário Oficial [da] República Federativa do Brasil, Brasília, DF, 5 out. 1988.

. Lei $n^{\circ}$ 9.394, de 20 de dezembro de 1996. Estabelece as Diretrizes e Bases da Educação Nacional. Diário Oficial [da] República Federativa do Brasil, Brasília, DF, 23 dez. 1996.

. Emenda Constitucional $n^{\circ}$ 59, de 11 de novembro de 2009. Acrescenta $\S 3^{\circ}$ ao art. 76 do Ato das Disposições Constitucionais Transitórias para reduzir, anualmente, a partir do exercício de 2009, o percentual da Desvinculação das Receitas da União incidente sobre os recursos destinados à manutenção e desenvolvimento do ensino de que trata o art. 212 da Constituição Federal, dá nova redação aos incisos I e VII do art. 208, de forma a prever a obrigatoriedade do ensino de quatro a dezessete anos e ampliar a abrangência dos programas suplementares para todas as etapas da educação básica, e dá nova redação ao $§$ 
$4^{\circ}$ do art. 211 e ao $\S 3^{\circ}$ do art. 212 e ao caput do art. 214, com a inserção neste dispositivo de inciso VI. Diário Oficial [da] República Federativa do Brasil, Brasília, DF, 12 nov. 2009.

Decreto $n^{\circ} 7.824$, de 11 de outubro de 2012. Regulamenta a Lei ${ }^{\circ} 12.711$ de 29 de agosto de 2012, que dispõe sobre o ingresso nas universidades federais e nas instituições federais de ensino técnico de nível médio. Diário Oficial [da] República Federativa do Brasil, Brasília, DF, 15 out. 2012a.

. Lei $n^{\circ} 12.711$, de 29 de agosto de 2012. Dispõe sobre o ingresso nas universidades federais e nas instituições federais de ensino técnico de nível médio e dá outras providências. Diário Oficial [da] República Federativa do Brasil, Brasília, DF, 30 ago. 2012 b.

- Ministério da Educação. Instituto Nacional de Estudos e Pesquisas Educacionais Anisio Teixeira. Censo Escolar da Educação Básica: 2012 - resumo técnico, 2013. Brasília: INEP, 2013a.

- Ministério da Educação. Instituto Nacional de Estudos e Pesquisas Educacionais Anísio Teixeira. Censo da Educação Superior: 2011 - resumo técnico, 2013. Brasília: INEP, 2013b.

CASTEL, R. A escolha do Estado social. Sociologias, Porto Alegre, v. 2, n. 3, p. 18-35, 2000.

DRIBE, S. Rumos e metamorfoses: um estudo sobre a constituição do Estado e as alternativas da industrialização no Brasil, 1930-1960. Rio de Janeiro: Paz e Terra, 2004.

ENGUITA, M. F. La igualdad, la equidad y otras complejidades de la justicia educativa. Revista Portuguesa de Educação, Braga, v. 26, n. 2, p. 205-224, 2013.

FRASER, N. Da redistribuição ao reconhecimento? Dilemas da Justiça na era Pós-socialista. In: SOUZA, J. (Org.). Democracia hoje: novos desafios para a teoria democrática contemporânea. Brasília: Ed. UnB, 2001.

FRIEDMAN, M. Capitalismo e liberdade. São Paulo: Abril, 1984.

GRAMSCI, A. Concepção dialética da história. 6. ed. Rio de Janeiro: Civilização Brasileira, 1986. 
- Cadernos do Cárcere: Maquiavel, notas sobre o Estado e a Política. Tradução de Carlos Nelson Coutinho e Luiz Sérgio Henriques. Rio de Janeiro: Civilização Brasileira, 2000. v. 3.

GRISA, G. D. As ações afirmativas na UFRGS: uma análise do processo de implantação. 2009. 96 f. Dissertação (Mestrado em Educação) - Faculdade de Educação, Universidade Federal do Rio Grande do Sul, Porto Alegre, 2009.

HONNETH, A. Luta por reconhecimento: a gramática moral dos conflitos sociais. São Paulo: Editora 34, 2009.

KONZEN, L. A justiciabilidade dos direitos sociais: considerações a respeito da eficácia jurídico-subjetiva dos direitos fundamentais. Espaço Jurídico, Joaçaba, v. 11, n. 1, p. 63-90, 2010.

LIAKOPOULOS, M. Análise argumentativa. In: BAUER, M. W.; GASKEL, G. (Org.). Pesquisa qualitativa com texto, imagem e som: um manual prático. Petrópolis: Vozes, 2002.

MARSHALL, T. H. Cidadania, classe social e status. Rio de Janeiro: Zahar, 1967.

MONSMA, K.; SOUZA, J. V. C.; SILVA, F. O. As consequências das ações afirmativas na Universidade Federal do Rio Grande do Sul: uma análise preliminar. In: SANTOS, J. T. (Org.). O impacto das cotas nas universidades brasileiras (2004-2012). Salvador: CEAO, 2013.

MULLER, P.; SUREL, Y. A análise de políticas públicas. Pelotas: Educat, 2002. (Coleção Desenvolvimento Social).

NEVES, C. E. B. N.; RAIZER, L.; FACHINETTO, R. F. Acesso, expansão e equidade na educação superior: novos desafios para a política educacional brasileira. Sociologias, Porto Alegre, v. 9, n. 17, p. 124-157, jan./jun., 2007.

OLIVEIRA, D. A. Gestão democrática da educação no contexto da reforma do Estado. In: FERREIRA, N. S. C.; AGUIAR, M. A. S. (Org.). Gestão da educação: impasses, perspectivas e compromissos. São Paulo: Cortez, 2001.

PIOVESAN, F.; VIEIRA, R. S. Justiciabilidade dos direitos sociais e econômicos no Brasil: desafios e perspectivas. Araucaria: Revista Iberoamericana de Filosofia, Politica y Humanidades, Sevilha, v. 8, n. 15, p. 5-30, jan./jun., 2006. 
RAWLS, J. Uma teoria da justiça. 3. ed. São Paulo: Martins Fontes, 2008.

SANTOS, B. S. Reinventar a democracia: entre o pré-contratualismo e o póscontratualismo. In: HELLER, A. et al. A crise dos paradigmas em Ciências Sociais e os desafios para o século XXI. Rio de Janeiro: Contraponto, 1999.

. A crítica da razão indolente: contra o desperdício da experiência. São Paulo: Cortez, 2000. v. 1.

SMITH, A. A riqueza das nações. São Paulo: Martins Fontes, 2003.

SOUZA, J. V. S. Alunos de escola pública na Universidade Federal do Rio Grande do Sul: portas entreabertas. 2009. 464 f. Tese (Doutorado em Educação) - Faculdade de Educação, Universidade Federal do Rio Grande do Sul, Porto Alegre. 2009.

UNIVERSIDADE FEDERAL DO RIO GRANDE DO SUL - UFRGS. Conselho Universitário - CONSUN Decisão $n^{\circ} 148$, de 23 de setembro de 1994. Estatuto. Diário Oficial [da] República Federativa do Brasil, Brasília, DF, 11 jan. 1995.

. Decisão $n^{\circ}$ 134, de 29 de junho de 2007. Porto Alegre: UFRGS, 2007. . Ata $n^{\circ} 1.151$, de 20 de julho de 2012. Porto Alegre: UFRGS, 2012.

WEBER, M. Economia e sociedade: fundamentos da sociologia compreensiva. Brasília: Ed. UnB, 1991. v. 1.

\section{Public policies of affirmative actions for Higher Education: The University Council as an arena of disputes \\ Abstract}

This article discusses the emergence of compensatory policies whose main focus has been to reserve places in public higher education for students who, due to their ethnic, racial and/or socioeconomic background, did not or still do not have access to this level of education. It addresses the relationship between the state, social justice and democracy seeking to provide the theoretical and conceptual support to the study of affirmative action policies for higher education in Brazil. Utilizing the methodological resource of argumentative analysis, it examines the 
conflicts and disputes established in the University Council meeting of the Federal University of Rio Grande do Sul in 2012, a period of review of the Affirmative Action program implemented at the university in 2008. As a general conclusion, it is postulated that the conflicts and disputes established by the segments of the Council, particularly faculty and students, express the disputes present in the Brazilian society for a model of social justice in view of public policies of affirmative action for higher education.

Keywords: Quotas for higher education. University Council. Welfare state. Social justice and democracy. Federal University of Rio Grande do Sul.

\section{Políticas públicas de acciones afirmativas para la Educación Superior: el Consejo Universitario como escenario de conflictos Resumen}

Este artículo discute la emergencia de politicas compensatorias cuyo objetivo principal ha sido el de reservar plazas en la educación superior pública para los estudiantes que, por motivos de su origen étnico, racial y/o socioeconómico, no tuvieron/tienen acceso a este nivel de educación. Aborda la relación entre el Estado, la justicia social y la democracia, buscando suministrar la base teórica y conceptual de políticas de acciones afirmativas para la educación superior en Brasil. Utilizando el recurso metodológico del análisis argumentativo, se examinan los conflictos y disputas establecidos en la reunión del Consejo Universitario de la Universidad Federal de Río Grande del Sur en el año 2012, periodo de evaluación del programa de Acciones Afirmativas, implantado en esta universidad en el año 2008. Como conclusión general, se postula que los conflictos y disputas establecidos por los segmentos del Consejo, en particular de profesores y estudiantes, expresan las disputas presentes en la sociedad brasileña por un modelo de justicia social frente a las políticas públicas de acciones afirmativas para la educación superior.

Palabras clave: Cupos para la educación superior. Consejo Universitario. Estado social. Justicia social y democracia. Universidad Federal de Río Grande del Sur.

\section{Informação do autor}

Neusa Chaves Batista: neuchaves@gmail.com 